\title{
Growth response of holm oak (Quercus ilex L) to commercial thinning in the Montseny mountains (NE Spain)
}

\author{
X Mayor, F Rodà \\ Centre de Recerca Ecologica i Aplicaciones Forestals (CREAF), \\ Universitat Autònoma de Barcelona, 08193 Bellaterra, Spain
}

(Received 17 August 1992; accepted 6 January 1993)

\begin{abstract}
Summary - Growth responses of holm oak (Quercus ilex) to commercial thinning were studied in the Montseny Biosphere Reserve (northeast Spain), where selection thinning for firewood production is currently the dominant form of management in holm oak forests. Thinning significantly increased mean stem diameter increment by $83 \%$ over that of unthinned plots during the $6-9$-yr period after thinning, and by $48 \%$ from $9-12 \mathrm{yr}$ after thinning. Absolute diameter increment was positively correlated with initial diameter at $1.30 \mathrm{~m}$ from the ground (dbh) both in thinned and unthinned plots. Thinning increased growth in large trees more than in smaller trees. Relative diameter growth was negatively correlated with initial $d b h$. It is concluded that individual holm oak stems in previously coppiced stands respond vigourously to thinning, and still do so 6-9 yr after thinning. The growth response diminishes 9-12 yr after thinning due to canopy closure. However, absolute rates of stand growth, as well as basal area and stem biomass increments, were unaffected by thinning during these time intervals, an example of density compensation.
\end{abstract}

canopy closure / Quercus ilex $=$ holm oak / selection thinning / stand growth / tree growth

Résumé - Effet d'une éclaircie commerciale sur la croissance d'un chêne vert (Quercus ilex L) dans les montagnes du Montseny (NE de l'Espagne). L'effet d'une éclaircie commerciale sur la croissance du chêne vert (Quercus ilex) a été étudié dans la réserve de la Biosphère du Montseny (NE Espagne). Dans cette région, l'éclaircie sélective pour la production du bois de chauffage est la forme la plus commune de gestion des forêts. L'éclaircie a augmenté l'accroissement de diamètre des tiges de 83\% par rapport aux placettes non éclaircies entre 6 et 9 ans et de $48 \%$ entre 9 et 12 ans après le traitement. L'accroissement absolu de diamètre est corrélé positivement avec le diamètre initial à 1,30 m. Les gros arbres ont davantage augmenté leur croissance que les petits. L'accroissement relatif en diamètre est corrélé négativement avec le diamètre initial à 1,30 m. On peut conclure que les tiges du chêne vert dans le taillis étudié ont une réponse vigoureuse à l'éclaircie et que cette réponse se prolonge encore 6 à 9 ans après. L'effet sur la croissance diminue 9 à 12 ans après l'éclaircie par suite de la fermeture du couvert végétal. Cependant, les taux absolus d'accroissement du peuplement, ainsi que la croissance de la surface terrière et de la biomasse des tiges, ne sont pas affectés par l'éclaircie pendant ces intervalles de temps, ce qui constitue un exemple de compensation de la densité.

fermeture de la couverture végétale / Quercus ilex = chêne vert / éclaircie sélective / accroissement du peuplement / croissance des tiges 


\section{INTRODUCTION}

Selection thinning is a standard silvicultural practice that has been successful in many forest types for sustained timber production in uneven-aged stands (Boudru, 1989). Additionally, thinning can be used to favour tree regeneration, improve the environmental conditions for wildlife, modify the likelihood and impact of disturbances, or create spatial patterns of community types and species richness (Johnson and Krinard, 1983; Frankling and Forman, 1987).

Thinning increases the availability of light, water and nutrients to the remaining trees. As a result, tree growth is usually increased after thinning. Growth responses to thinning have been modeled to provide increased knowledge to be applied in forestry (Hibbs and Bentley, 1984; Piennar and Shiver, 1984; Whyte and Wollons, 1990). Thinning effects on tree growth are usually studied in terms of stem diameter increment, height growth, and canopy expansion of the remaining trees (Hamilton, 1981; Ducrey, 1988; Baldwin et al, 1989; Bouchon et al, 1989; Cutter et al, 1991), but effects on production of stump resprouts (Ducrey and Boisserie, 1992; Retana et al, 1992) and epicormic sprouts (Paysen et al, 1991) have been studied as well. Growth responses to thinning are relatively well known in many coniferous (Hamilton, 1981; Baldwin et al, 1989; Whyte and Woollons, 1990) and deciduous broad-leaved species (Bouchon et al, 1989; Cutter et al, 1991).

A peculiar situation arises in extensive tracts of Mediterranean hardwood forests that were intensively coppiced in the past for charcoal production, resulting in high density even-aged stands of relatively small stump resprouts. After abandonment of charcoal production in the 1950s, many private owners shifted in the early 1970 s to selection thinning for firewood, a silvicultural method that was previously practised only to a limited extent. This important management change is widespread in holm oak forests in the region of relatively high rainfall in northeast Spain. Usually about one-third to one-half of the canopy trees are cut at intervals from 18-25 yr, changing the stand to an uneven-aged stand. There is very little quantitative information on the effects of such change, either on tree growth and forest production or on its ecological consequences.

The purpose of this paper is to report results on tree and stand growth after a commercial thinning of a holm oak stand, in the $6-12-y r$ interval after thinning.

\section{MATERIAL AND METHODS}

\section{Study site}

This study was carried out within the Torrent de la Mina catchment at La Castanya Biological Station $\left(41^{\circ} 46^{\prime} \mathrm{N}, 2^{\circ} 21^{\prime} \mathrm{E}\right)$ in the Montseny mountains, a natural park and biosphere reserve in northeast Spain. The lower half of this 200-ha catchment is covered by a dense holm oak forest where biomass, primary production and nutrient cycling have been extensively investigated (Ferrés et al, 1984; Escarré et al, 1987; Avila and Rodà, 1988; Caritat and Terradas, 1990; Mayor, 1990; Rodà et al, 1990; Canadell and Rodà, 1991; Bonilla and Rodà, 1992; Mayor and Rodà, 1992). Climate is subhumid Mediterranean with a mean annual precipitation of $870 \mathrm{~mm}$. The bedrock is a metamorphic phyllite and soils are rather shallow, sandy-loam dystric xerochrepts with a high stone content. Slopes are very steep (mean $34^{\circ}$ ). Holm oak is virtually the only tree species in the tree layer. The understory is sparse. Most of this forest has not been disturbed since the end of charcoal production in the 1950s. The present stand structure is dominated by multi-stemmed trees originating from stump resprouting, though single-stemmed trees are also common. 


\section{Field measurements}

For this study we took advantage of a commercial thinning carried out in 1979 by the private owner of a sector of the east-facing slope of the catchment, at an altitude of $900 \mathrm{~m}$. Estimated mean annual temperature at this topographic position is $11-12^{\circ} \mathrm{C}$. In late June 1985,4 replicate plots were laid out within the thinned area, and 3 control plots in an adjacent unthinned area. Since the thinning was commercial instead of experimental, thinned and unthinned plots could not be interspersed. However, the thinned and unthinned plots were very close together, had the same slope aspect and steepness and similar soil. Aerial photographs taken in 1978 before thinning confirmed that the forest was quite homogeneous.

Circular plots with an area of $154 \mathrm{~m}^{2}$ were used. When the plots were laid out, $d b h$ (diameter at $1.30 \mathrm{~m}$ from the ground) was measured for all living stems forming the tree layer ( $d b h \geq$ $5 \mathrm{~cm}$ ). All stems were permanently numbered and a line was painted on the exact point along the stem where diameter was measured. This greatly increased the accuracy of stem diameter increments determined from repeated measurements. Stem diameters were remeasured in July 1988 and July 1991. Diameter increment (over bark) for each stem during each period of 3 or 6 yr (1985-1988, 1988-1991, and 1985-1991) was determined from difference in diameter at both dates. Stem biomass (wood plus bark of the trunk and branches down to $5 \mathrm{~cm}$ in diameter) for each stem was estimated for each date through an allometric regression on dbh derived for this holm oak forest. From the several available regressions (Canadell et al, 1988), that for trees 4-7 $\mathrm{m}$ in height was used, since height of most stems was within this range. The regression was:

$$
\begin{gathered}
\log S B=-0.747+2.044 \log d b h \\
\left(n=33, r^{2}=0.93, S^{y \cdot x}=0.073\right)
\end{gathered}
$$

where $S B$ is stem biomass ( $\mathrm{kg}$ dry weight), and $d b h$ is in $\mathrm{cm}$. We preferred to estimate stem biomass instead of total aboveground biomass because, as here defined, it is the component of the tree utilized for firewood, and because total biomass includes the biomass of fine branches and leaves. The latter components are rather dynamic and their allometric relationships with $d b h$ are likely to change as a result of thinning. Conversely, for stem biomass the slow rates of growth displayed by holm oak makes unlikely that allometric relations with $d b h$ change to any significant extent during the first $12 \mathrm{yr}$ after thinning. Stem biomass increment was determined as the difference between biomass at initial and final dates for the periods 1985-1988, 19881991 and 1985-1991.

\section{Statistical analysis}

Effects of thinning on stem diameter growth rates over the whole study period were tested by a $t$-test, using the arithmetic mean diameter growth rate of each plot, and by an analysis of covariance (ANCOVA) of individual growth rates using initial stem diameter ( $d b h)$ as a covariate. Time-dependence of tree and stand growth rates were tested by repeated measures analysis of variance. To guard against the effect of autocorrelation in the dependent variable(s), Greenhouse-Geisser and Hunyh-Feldt epsilon estimates were used to correct the $P$-values. In no case did these corrections affect the result of the analyses and are not reported here. Analyses were performed with the SuperANOVA statistical package (Abacus Concepts, 1989).

During the study period, 9 out of 230 tallied holm oak stems developed cracks or bumps at the point of diameter measurement, preventing a meaningful reading of their diameter increments. These stems were not taken into account in analyses involving stem growth rates. When considering stand growth rates (basal area and biomass increments), diameter of these 9 stems at the dates of interest were estimated by linear regression of final $d b h$ on initial $d b h$.

\section{RESULTS}

\section{Stand structure}

At the start of the study, ie 6 yr after thinning, density and basal area of the tree layer were, as expected, significantly higher in unthinned than in thinned plots. Mean 
density was $2837 \pm 348$ (SE) stems $\cdot$ ha $^{-1}$ in unthinned plots, and $1608 \pm 77$ (SE) stems $\cdot$ ha $^{-1}$ in thinned plots $(t=4.0, \mathrm{df}=5$, $P=0.01$ ). Mean basal area was $28.2 \pm 4.5$ (SE) $\mathrm{m}^{2} \cdot \mathrm{ha}^{-1}$ in unthinned plots, and 11.3 \pm 1.0 (SE) $\mathrm{m}^{2} \cdot \mathrm{ha}^{-1}$ in thinned plots $(t=$ $3.8, \mathrm{df}=5, P=0.013$ ). Mortality from $6-12$ $\mathrm{yr}$ after thinning was very low. Summing over all plots, only 4 out of 230 initial stems died during this $6-y r$ period. This yielded a mean annual mortality rate of $0.3 \%$. Ingrowth to the tree layer $(d b h \geq 5$ $\mathrm{cm}$ ) is also very limited in unthinned holm oak plots in this area (Mayor and Rodà, unpublished data) because virtually all stems with $d b h<5 \mathrm{~cm}$ are suppressed stems having no or negligible diameter growth. Stump sprouts were abundant in the thinned plots but none of these had reached a $d b h$ of $5 \mathrm{~cm}$ even $12 \mathrm{yr}$ after thinning. Therefore, as mortality and ingrowth were negligible, stem density of the tree layer measured $6 \mathrm{yr}$ after thinning should be nearly the same as that just after thinning. In this way we can estimate that this commercial thinning removed $43 \%$ of the holm oak stems having a $d b h \geq$ $5 \mathrm{~cm}$. This thinning intensity is common for thinnings undertaken by private owners at Montseny. The same computation cannot be applied to estimate the percentage of basal area removed, since basal areas must have changed during the first $6 \mathrm{yr}$ after thinning. However, it must be noted than thinning intensity was higher in terms of basal area removed than it was in number of stems, because thinning was more intense in the larger size classes, as is commonly the case at Montseny. This can be deduced from the higher quadratic mean diameter still detectable $6 \mathrm{yr}$ after thinning in unthinned plots $(11.2 \mathrm{~cm})$ than in thinned plots $(9.7 \mathrm{~cm})$. As a result of the size-selective thinning, stems with a $d b h \geq$ $15 \mathrm{~cm}$ accounted for $15 \%$ of the number of stems in the unthinned plots but only $3 \%$ in the thinned plots (fig 1 ).
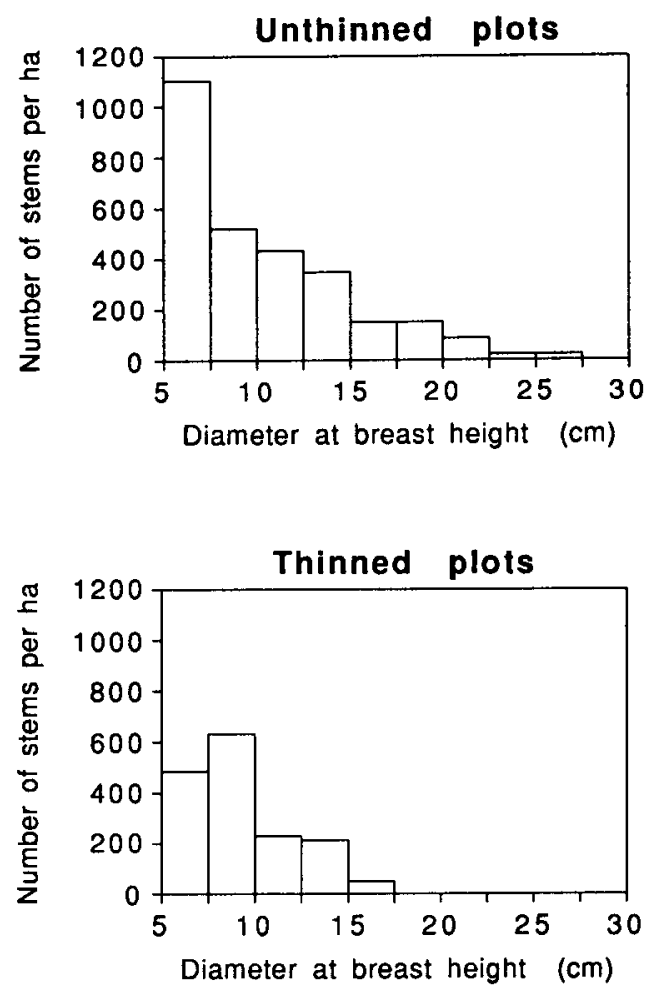

Fig 1. Diameter distribution of holm oak stems in the 3 unthinned and 4 thinned plots in late June 1985 (ie 6 yr after thinning).

\section{Tree growth}

\section{Absolute stem diameter increment}

Mean absolute stem diameter increment during the interval from $6-12$ yr after thinning was $0.83 \mathrm{~mm} \cdot \mathrm{yr}^{-1}( \pm 0.05 \mathrm{SE}, n=3)$ for unthinned plots, and $1.43 \mathrm{~mm} \cdot \mathrm{yr}^{-1}$ $( \pm 0.04 \mathrm{SE}, n=4)$ for thinned plots. The effect of thinning was highly significant $(t=$ 9.7, $\mathrm{df}=5, P=0.0002$ ).

The time-dependence of the above effect can be addressed by analyzing separ- 
ately data for the period 1985-1988 (6$9 \mathrm{yr}$ after thinning) and 1988-1991 (9-12 yr after thinning), as shown in table I. A repeated measures analysis of variance was used to evaluate significance of differences through time and those due to treatment (thinned versus unthinned). Both time and treatment had a significant effect ( $P=0.002$ in both cases). No interaction between treatment and time was found. Stem diameter increments were higher for thinned than for unthinned plots, and were higher during the first period (1985-1988) than the second (1988-1991) for both thinned and unthinned plots (table I). Thinning increased mean stem diameter increment by $83 \%$ over that of unthinned plots during the period 6-9 yr after thinning, and by $48 \%$ from $9-12$ yr after thinning.

Absolute increments $\left(\mathrm{mm} \cdot \mathrm{yr} \mathrm{r}^{-1}\right)$ in stem diameter of individual holm oaks during the interval from 6-12 yr after thinning were weakly but positively and significantly correlated with initial stem diameter, both in thinned and unthinned plots $(P=0.0002$, $r=0.38$ and $P=0.0001, r=0.34$, respectively). Thus, large trees showed on average higher absolute growth rates than smaller ones. Linear regressions between stem diameter increment $\left(y, \mathrm{~mm} \cdot \mathrm{yr}^{-1}\right)$ and initial $d b h(x$, in $\mathrm{cm})$ were for trees in unthinned plots:

$$
\begin{gathered}
y=0.29+0.052 x \\
\left(n=122, S_{y \cdot x}=0.70\right)
\end{gathered}
$$

and for trees in thinned plots:

$$
\begin{gathered}
y=0.56+0.096 x \\
\left(n=95, S_{y \cdot x}=0.68\right)
\end{gathered}
$$

An ANCOVA was run to test whether thinning still had a significant effect on diameter growth after discounting the effect of initial $d b h$, and whether there was a significant interaction between thinning and initial $d b h$. The full ANCOVA model included terms for treatment (thinned or unthinned), initial $d b h$ as covariate, and the interaction between both. This full model gave a significant effect of $d b h\left(F_{1.213}=\right.$ 28.0, $P=0.0001$ ), as expected from the above regressions; a non-significant effect of treatment $\left(F_{1.213}=0.98, P=0.32\right)$, and a doubtfully significant interaction $\left(F_{1.213}=\right.$ $2.5, P=0.12$ ). The ANCOVA was then repeated deleting the non-significant treatment term, with the result that not only the initial dish but also the interaction between

Table I. Mean stem diameter increment of holm oak trees in unthinned $(n=3)$ and thinned $(n=4)$ plots (SE in parentheses).

\section{Treatment}

Period

1985-1988 1988-1991 1985-1991

Mean absolute diameter increment $\left(\mathrm{mm}_{\mathrm{yr}} \mathrm{r}^{-1}\right)$

Unthinned

Thinned

$1.06(0.19)$
$1.94(0.07)$

$0.61(0.11)$

$0.90(0.03)$

$0.83(0.05)$

$1.43(0.04)$

\section{Mean relative diameter increment $\left(\% y r^{-1}\right)$}

Unthinned

Thinned 
thinning and $d b h$ became highly significant $\left(F_{1.214}=53.8, P=0.0001\right)$. This means that thinning increased absolute diameter growth rates more in larger trees than in smaller ones: mean diameter increments where $138 \%$ higher in thinned than in unthinned plots for trees of $d b h 11-15 \mathrm{~cm}$, and $98 \%$ higher for trees of $d b h 5-8 \mathrm{~cm}$.

\section{Relative stem diameter growth}

Relative growth rates in stem diameter were computed for individual stems dividing the annualised absolute increment $\left(\mathrm{mm} \mathrm{yr}^{-1}\right)$ in a given period by the stem diameter at the start of the period, and expressing the result as a percentage. Mean relative diameter increments during the interval from 6-12 $\mathrm{yr}$ after thinning were $0.87 \% \mathrm{yr}^{-1}$ and $1.64 \% \mathrm{yr}^{-1}$, in unthinned and thinned plots, respectively (table I). As opposed to absolute diameter increments, relative diameter growth rates during the interval from 6-12 yr after thinning were weakly but negatively and significantly correlated with initial stem diameter $(P=$ $0.025, r=-0.20$ for unthinned plots, and $P=0.016, r=-0.25$ for thinned plots). The corresponding linear regressions between relative diameter growth rates over this 6yr period $\left(y, \% y^{-1}\right)$ and initial $d b h(x, c m)$ were, for trees in unthinned plots:

$$
\begin{aligned}
& y=1.20-0.0319 x \\
& \left(n=122, S_{y . x}=7.5\right)
\end{aligned}
$$

and for trees in thinned plots:

$$
\begin{gathered}
y=2.27-0.0692 x \\
\left(n=95, S_{y, x}=7.8\right)
\end{gathered}
$$

The ANCOVA gave significant effects of both thinning $\left(F_{1.213}=12.1, P=0.0006\right)$ and initial $d b h\left(F_{1.213}=10.7, P=0.001\right)$, without significant interaction between them. The repeated measures analysis of variance gave significant effects for treatment and time $(P<0.002$ in both cases), and for their interaction $(P=0.026)$. The interaction arose because during the first period (1985-1988) relative diameter increment was much higher in thinned than in unthinned plots while this difference decreased in the second period: mean relative diameter increment was $108 \%$ higher in thinned than in unthinned plots during 6-9 yr after thinning, but only $47 \%$ higher during 9-12 yr after thinning (table I).

\section{Stand growth}

\section{Basal area increment}

During the interval from 6-12 yr after thinning, mean basal area of the tree layer increased in the unthinned plots from 28.2 to $30.2 \mathrm{~m}^{2} \cdot \mathrm{ha}^{-1}$ (table II). Mean basal area in the unthinned plots increased from 11.3$13.4 \mathrm{~m}^{2} \cdot \mathrm{ha}^{-1}$. Mean annual basal area increment was 0.33 and $0.35 \mathrm{~m}^{2} \cdot \mathrm{ha}^{-1} \cdot \mathrm{yr}^{-1}$ in unthinned and thinned plots, respectively (table II).

As before, a repeated measures analysis of variance was used with absolute and, separately, relative basal area increments as dependent variables. The latter was calculated dividing the absolute basal area increment of each plot by the basal area at the start of the considered period, and expressing the result as a percentage (table III). For absolute increments, neither thinning, time, nor their interaction were significant $(P>0.29$ in all cases). For relative increments, both thinning and time were significant $(P=0.0006$ and $P=0.02$, respectively), while the interaction between them was marginally significant ( $P=$ 0.056). Relative basal area increment had to be higher in thinned plots, as we found, since absolute basal area growth was not 
Table II. Mean basal area, stem biomass, basal area increment and stem biomass increment for unthinned $(n=3)$ and thinned $(n=4)$ plots in each year or period considered (SE in parentheses).

\begin{tabular}{|c|c|c|c|c|c|c|}
\hline \multirow[t]{2}{*}{ Treatment } & \multicolumn{3}{|c|}{ Year } & \multicolumn{3}{|c|}{ Period } \\
\hline & 1985 & 1988 & 1991 & $1985-1988$ & $1988-1991$ & $1985-1991$ \\
\hline & \multicolumn{3}{|c|}{ Basal area $\left(m^{2} \cdot h^{-1}\right)$} & \multicolumn{3}{|c|}{ Basal area increment $\left(\mathrm{m}^{2} \cdot \mathrm{ha}^{-1} \cdot \mathrm{yr}-{ }^{-1}\right)$} \\
\hline Unthinned & $28.2(4.5)$ & $29.2(4.5)$ & $30.2(4.6)$ & $0.35(0.20)$ & $0.31(0.089)$ & $0.33(0.07)$ \\
\hline \multirow[t]{2}{*}{ Thinned } & $11.3(1.0)$ & $12.7(1.1)$ & $13.4(1.1)$ & $0.47(0.03)$ & $0.23(0.021)$ & $0.35(0.02)$ \\
\hline & \multicolumn{3}{|c|}{ Stem biomass (t.ha ${ }^{-1}$ ) } & \multicolumn{3}{|c|}{ Stem biomass increment (t.ha- $\left.\mathrm{a}^{-1} \cdot \mathrm{y} \mathrm{r}^{-1}\right)$} \\
\hline Unthinned & $72.0(11.7)$ & $74.8(11.8)$ & $77.3(12.1)$ & $0.94(0.53)$ & $0.82(0.23)$ & $0.88(0.17)$ \\
\hline Thinned & $28.5 \quad(2.6)$ & 32.2 & $34.0 \quad(2.9)$ & $1.22(0.07)$ & $0.60(0.06)$ & $0.91(0.06)$ \\
\hline
\end{tabular}

Table III. Mean relative annual increment $\left(\% \mathrm{yr}^{-1}\right)$ of basal area for unthinned $(n=3)$ and thinned $(n=4)$ plots for each period studied (SE in parentheses).

\begin{tabular}{|c|c|c|c|}
\hline Treatment & & Period & \\
\hline & $1985-1988$ & $1988-1991$ & $1985-1991$ \\
\hline
\end{tabular}

Unthinned $1.37(0.74) \quad 1.08(0.25) \quad 1.24(0.27)$

Thinned $4.22(0.16) \quad 1.83(0.06) \quad 3.14(0.08)$

affected by thinning whilst initial basal area was much reduced by it.

\section{Stem biomass increment}

During the interval from 6-12 yr after thinning, mean stem biomass in unthinned plots increased from 72.0-77.3 $\mathrm{t} \cdot \mathrm{ha}^{-1}$ (table II), while that of thinned plots increased from 28.5 to 34.0 t.ha $^{-1}$. Mean increments in stem biomass were 0.88 and $0.91 \mathrm{t} \cdot \mathrm{ha}^{-1} \mathrm{yr}^{-1}$ for unthinned and thinned plots, respectively. It should be noted that the above increments slightly underestimate stem production since some stem mortality occurred during this period.

A repeated measures analysis of variance with absolute and, separately, relative stem biomass increments (the latter calculated as explained for the relative basal area increment) as dependent variables yielded the same results as described for basal area growth. This is no surprise since basal area is a function of squared $d b h s$, and stem biomass is an allometric function of $d b h$ raised to an exponent of 2.04 (see Methods).

\section{DISCUSSION}

In 18 plots of closed holm oak forest spanning most of the topographic variation within the Torrent de la Mina catchment, the mean diameter increment during 19851988 was $0.87 \mathrm{~mm} \cdot \mathrm{yr}^{-1}$ (Mayor, 1990). Our results for the unthinned plots are very similar: $1.06 \mathrm{~mm} \cdot \mathrm{yr}^{-1}$ for the same period, and $0.83 \mathrm{~mm} \cdot \mathrm{yr}^{-1}$ for the whole $6-\mathrm{yr}$ period. Similar growth rates $\left(1.05 \mathrm{~mm} \cdot \mathrm{yr}^{-1}\right)$ 
were found in a lowland, unthinned holm oak coppice on calcareous bedrock in southern France (Ducrey and Toth, 1992), where mean precipitation is slightly higher than at Montseny ( $\left.1000 \mathrm{~mm} \cdot \mathrm{yr}^{-1}\right)$. In contrast, holm oak diameter increments were much smaller $\left(0.27 \mathrm{~mm} \cdot \mathrm{yr}^{-1}\right)$ in the Prades mountains $(120 \mathrm{~km}$ southwest of Montseny) probably due to the lower rainfall and very high stand density (Mayor and Rodà, submitted).

Holm oak at Montseny showed a positive growth response to thinning, as evidenced by enhanced growth rates for stem diameter, and for relative increments of basal area and stem biomass. For all these variables thinning increased growth rates around 2-fold. Mean diameter increment in thinned plots was $1.43 \mathrm{~mm} \cdot \mathrm{yr}^{-1}$. Similar results were found by Ducrey and Toth (1992) in a holm oak coppice where a moderate thinning treatment with a reduction in basal area of $40-45 \%$ yielded a mean diameter increment of $1.50 \mathrm{~mm} \cdot \mathrm{yr}^{-1}$. The commercial thinning we studied reduced stem density by $43 \%$, and reduction in basal area must have been greater. Retana et al (1992) found a mean basal area reduction of $(67 \% \pm 5 \mathrm{SE})$ for holm oak stands in another Montseny site. However, most forest owners at Montseny do not conduct thinning on a quantitative basis, and thinning intensity can change from one owner to another and from year to year.

Holm oak responded to thinning differently according to tree size. In absolute terms, growth of large stems was stimulated by thinning more than that of smaller trees. Large trees probably have a greater capacity for resource acquisition, and are thus more able to taken advantage of the increase in resource availability that takes place after thinning, and to eventually use these resources for growth. More specifically, a higher capacity for canopy expansion, more vigorous branches, and higher uptake of water and nutrients from a larger root system, are probably involved in this response.

Growth response to thinning was very strong in the interval from 6 to $9 \mathrm{yr}$ after thinning, and declined in the period 9-12 yr after thinning. Using dendrochronological methods, Cutter et al (1991) found that Quercus vetulina (a deciduous oak) showed increased growth responses to thinning until 10-12 yr after thinning, growth rates felling then to pre-thinning values. In our case, the reduced growth response 9-12 yr after thinning can be linked to canopy closure around this time. Inspection of thinned plots $12 \mathrm{yr}$ after thinning revealed that canopy closure was almost complete.

Effects of thinning on tree growth are best conceptualized by considering thinning as a man-made disturbance that reduces the stand density and increases the availability of resources for the remaining trees. Increased availability of space, light, water and nutrients implies a decrease in competition between trees. Thinning releases previously occupied space; this, together with increased light reaching the crowns of the remaining trees, allows for crown expansion through shoot elongation and growth of lateral shoots. These general response patterns hold both for trees derived from seed or from resprouting.

Holm oaks in thinned stands at Montseny show relatively fast rates of canopy expansion in the few first years after thinning (Mayor and Rodà, unpublished data). Wider and denser crowns result in a higher leaf area of each individual stem after thinning, thus increasing the light interception capacity of the tree. Interestingly, Hamilton (1981) found that in thinned stands where crowns had been experimentally reduced, the observed growth response was less than expected for the same thinning intensity without crown reduction. Water and 
nutrients are also more available after thinning. Relative availability of these soil resources increases merely because there are fewer remaining trees to share them. In addition, the absolute amounts of available water and nutrients often also increase after thinning, due to reduced interception of precipitation and faster mineralization rates (Binkley, 1986). Thinning can also lengthen the growing season (Bouchon et al, 1989) allowing the trees more time for growing.

We have demonstrated in this study that individual holm oak stems in previously coppiced stands respond vigourously to thinning, and that they still do so 6-9 yr after thinning. The growth response diminishes 9-12 yr after thinning due to canopy closure. However, absolute rates of stand growth, as basal area and stem biomass increments, are unaffected by thinning during these time intervals. This is an example of the law of constant final yield (Kira et al, 1953), better known in forestry as Eichhorn's law or Langsaetter's relation which states that over a wide range of tree densities, total yields are the same (Perry, 1985). Thus, forest production is relatively constant in front of thinning intensity (Assmann, 1970) as we found in this study. Many open questions related to selection thinning in Mediterranean forests merit further study. For instance, effects of thinning intensity on canopy dynamics as related to light and nutrient regimes, on stand regeneration by sprouts and seedlings, and on wildlife habitats should be known for a proper use of this silvicultural practice.

\section{ACKNOWLEDGMENTS}

Collaboration in fieldwork from many colleagues and students is gratefully acknowledged. This work was partly funded by a grant from the Caixa d'Estalvis de Barcelona and by CICYT project FOR 90-0432.

\section{REFERENCES}

Abacus Concepts (1989) SuperANOVA. Abacus Concepts Inc, Berkeley, CA

Assmann E (1970) The Principles of Forest Yield Study. Pergamon, Oxford

Avila A, Rodà $F$ (1988) Export of dissolved elements in an evergreen-oak forested watershed in the Montseny mountains (northeast Spain). Catena suppl 12, 1-11

Baldwin VC Jr, Feduccia DP, Haywood JD (1989) Post-thinning and yield of row-thinned and selectively thinned loblolly and slash pine plantations. Can J For Res 19, 247-256

Binkley D (1986) Forest Nutrition Management. Wiley, New York

Bonilla $D$, Rodà $F$ (1992) Soil nitrogen dynamics in a holm oak forest. Vegetatio $99 / 100,247$ 257

Bouchon J, Dhôte JF, Lanier L (1989) Réaction individuelle de hêtres (Fagus sylvatica L) d'âges divers à diverses intensités d'éclaircie. Ann Sci For 46, 251-259

Boudru M (1989) Forêt et Sylviculture: Traitement des Forêts. Presses Agron Gembloux, Gembloux

Canadell J, Riba M, Andrés P (1988) Biomass equations for Quercus ilex $L$ in the Montseny massif, northeastern Spain. Forestry 61, 137147

Canadell J, Rodà F (1991) Root biomass of Quercus ilex in a montane Mediterranean forest. Can J For Res 21, 1771-1778

Caritat A, Terradas J (1990) Micronutrients in biomass fractions of holm oak, beech and fir forests of the Montseny massif (Catalonia, northeast Spain). Ann Sci For 47, 345-352

Cutter BE, Lowell KE, Dwyer JP (1991) Thinning effects on diameter growth in black and scarlet oak as shown by tree ring analyses. For Ecol Manage 43, 1-13

Ducrey M (1988) Recherches de I'Institut $\mathrm{Na}$ tional de la Recherche Agronomique sur la sylviculture des taillis de chênes verts. For Médit 1, 125-129

Ducrey M, Boisserie M (1992) Recrû naturel dans des taillis de chêne vert (Quercus ilex L) à la suite d'exploitations partielles. Ann $S c i$ For 49, 91-109 
Ducrey M, Toth J (1992) Effect of cleaning and thinning on height growth and girth increment in holm oak coppices (Quercus ilex L). Vegetatio 99/100, 365-376

Escarré A, Ferrés L, López R, Martín J, Rodà F, Terradas $J$ (1987) Nutrient use strategy by evergreen oak (Quercus ilex ssp ilex) in northeast Spain. In: Plant Response to Stress (JD Tenhunen et al, eds) Springer, Berlin, 429-435

Ferrés L, Rodà $F$, Verdú AMC, Terradas $J$ (1984) Circulación de nutrientes en algunos ecosistemas forestales del Montseny (BarceIona). Med Ser Biol 7, 139-166

Franklin J, Formann RTT (1987) Creating landscape patterns by forest cutting: ecological consequences and principles. Landscape Ecol 1, 5-18

Hamilton GJ (1981) The effects of high intensity thinning on yield. Forestry 54, 1-15

Hibbs DE, Bentley WR (1984) A growth model for red oak in New England. Can J For Res 14, 250-254

Johnson RL, Krinard RM (1983) Regeneration in small and large sawtimber sweetgum-red oak stands following selection and seed tree harvest. Southern J Appl For 7, 176-184

Kira T, Ogawa H, Shinozaki K (1953) Intraspecific competition among higher plants. I. Competition-density-yield interrelationships in regularly dispersed populations. J Inst Polytech Osaka Cy Univ D4, 1-16
Mayor FX (1990) El paper dels nutrients com a factors limitants de la producció primària de l'alzinar de la conca del Torrent de la Mina (Montseny). Master's dissertation, Univ Autònoma de Barcelona

Mayor FX, Rodà F (1992) Is primary production in holm oak forests nutrient limited? A correlational approach. Vegetatio 99/100, 209-217

Paysen TE, Narog MG, Tissell RG, Lardner MA (1991) Trunk and root sprouting on residual trees after thinning a Quercus chrysolepis stand. For Sci 37, 17-27

Perry DA (1985) The competition process in forest stands. In: Trees as Crop Plants (MGR Cannell, GE Jackson, eds) Inst Terrestr Ecol, Huntingdon, UK

Piennar LV, Shiver BD (1984) An analysis and models of basal area growth in 45-year-old unthinned and thinned slash pine plantations plots. For Sci 30, 933-942

Retana J, Riba M, Castell C, Espelta JM (1992) Regeneration by sprouting of holm-oak (Quercus ilex) stands exploited by selection thinning. Vegetatio 99/100, 355-364

Rodà F, Avila A, Bonilla D (1990) Precipitation, throughfall, soil solution and streamwater chemistry in a holm oak (Quercus ilex) forest. J Hydrol 116, 167-183

Whyte AGD, Woollons RC (1990) Modelling stand growth of radiata pine thinned to varying densities. Can J For Res 20, 1069-1076 